\title{
PERLINDUNGAN HUKUM BAGI ANAK DALAM PERSPEKTIF PANCASILA DAN BELA NEGARA
}

\author{
Laurensius Arliman S \\ Sekolah Tinggi IImu Hukum Padang \\ E-mail: laurensiusarliman@gmail.com
}

Sitasi : Arliman S, Laurensius. Perlindungan Hukum Bagi Anak Dalam Perspektif Pancasila dan Bela Negara. UNIFIKASI Jurnal I/mu Hukum, 5(1), 58-70. DOI : https://doi.org/10.25134/unifikasi.v5i1.754

Naskah diterima : 5-12-2017 Naskah direvisi : 22-1-2018

Naskah disetujui : 29-1-2018

\begin{abstract}
Abstrak : Pancasila adalah Ideologi dan sumber dari segala pembentukan perturan perundang-undangan yang ada di Indonesia. Undang Undang Dasar Negara Republik Indonesia Tahun 1945 dan Undang Undang Bela Negara mengisyaratkan agar setiap masyarakat melaksanakan pertahanan negara, demi menjaga keutuhan NKRI. Tujuan penelitian ini adalah untuk menegtahui dan menganalisis bagaimana kedudukan Pancasila sebagai Ideology Indonesia? dan bagaimana mewujudkan perlindungan anak sebagai cita-cita bela negara. Metode penelitian yaitu metode pendekatan yuridis normatif yang menitik beratkan penggunaan bahan atau meteri penelitian data sekunder dengan di dukung oleh data kepustakaan. Hasil penelitain adalah Nilai-nilai luhur yang terkandung dalam Pancasila sebagai ideologi bangsa seharusnya bukan hanya untuk diketahui saja tetapi harus dimengerti yang kemudian diamalkan dikehidupan sehari-hari dalam berabagai aspek kehidupan. Perlakuan yang sama terhadap setiap warga Negara Indonesia (terkhususnya terhadap perlindungan anak) dalam bidang hukum, juga harus menerapakan nilai-nilai luhur yang terkandung dalam Pancasila dan Melalui bela negara akan terbangun karakter disiplin, optimisme, kerjasama dan kepemimpinan guna turut menjamin kelangsungan hidup bangsa dan negara. Kita sebagai warga negara wajib mengupayakan untuk membela negara. Kesimpulan, kita sebagai generasi penerus mempunyai kewajiban untuk memberi contoh bela negara, sesuai dengan arti atau pengertian bela negara Indonesia yaitu seperti belajar bersungguh-sungguh serta taat terhadap peraturan perundang-undangan. Hal itu diwujudkan dalam bentuk perlindungan anak berkelanjutan. Perlindungan anak berkelanjutan, akan menciptakan generasi penerus bangsa yang mempertahankan dan membela Negara Indonesia.
\end{abstract}

Kata Kunci: ideologi, Pancasila, perlindungan, anak, bela negara.

\section{THE LAW PROTECTION OF CHILDREN IN THE PANCASILA PERSPECTIVE AND STATE DEFENSE}

Abstrak : Pancasila is a ideology and the source of any formulation of existing laws and regulations in Indonesian. The 1945 Constitution of the Republic Indonesia and the state defebse act of the Republic Indonesia, in order to maintan the integrety of NKRI. the aims to knows and analyze how to position of Pancasila as Ideology Indonesian and how to realize the protection of children as the ideals of satet defense. This research method used normative juridical approach that emphasizes the use of naterials seconadry data with the support by literature study. The result of research is the noble values contained in Pancasila as the nation's ideology to know, understood which then must be practiced in everyday life in various aspects of life. The equal treatment of every citizen of Indonesia (especially against child protection) in the field of law, the application of values contained in Pancasila in the state defense that will build the character of discipline, optimism, cooperation and leadership, the form of ensuring the survival of the nation and state, we as citizens must strive to defend the country. In conclusion, we as the next generation have an obligation to be an example of defending the country, in accordance with the meaning or understanding of defending the state of Indonesia as in studying seriously and obedient to the laws and regulations. It is manifested in the form of sustainable child protection. The continuous child protection, will create the next generation of nation that defends and defends the State of Indonesia.

Keywords: ideology, Pancasila, protection, children, defend state.

\section{PENDAHULUAN}

Negara Kesatuan Republik Indonesia (NKRI) yang diproklamasikan pada tanggal 17 Agustus 1945, merupakan buah perjuangan panjang para pejuang bangsa. Pengorbanan yang gigih baik itu waktu, tenaga maupun pikiran dan nyawa serta dilandasi kesatuan dan persatuan serta pantang menyerah dari seluruh rakyat Indonesia, sehingga kita dapat menghadapi penjajah bahkan mengusirnya. Keberhasilan merebut dan mempertahankan NKRI, maka bangsa Indonesia dikenal sebagai bangsa yang heroik dan disegani bangsa lain di dunia. Keberhasilan bangsa Indonesia 
UNIFIKASI : Jurnal IImu Hukum, Volume 05 Nomor 01, Januari 2018

dalam merebut, dan mempertahankan NKRI dari negara penjajah (Belanda dan Jepang) tersebut menjadikan lahirnya Negara dan bangsa Indonesia melalui proses perjuangan panjang bukan semata-mata hadiah dari bangsa lain. Sungguh perjuangan yang dilaksanakan bangsa Indonesia tersebut mendapatkan ridho Tuhan Yang Maha Esa dan pada gilirannya perjuangan tersebut merupakan nilai-nilai luhur bangsa Indonesia yang harus di wariskan dari satu generasi ke generasi selanjutnya.

Sependapat dengan hal tersebut, sejak awal berdirinya NKRI, kebhinekaan merupakan kekayaan Negara Indonesia yang harus diakui, diterima, dan dihormati. Kemajemukan sebagai anugerah juga harus dipertahankan, dipelihara, dan dikembangkan yang kemudian diwujudkan dalam semboyan Bhineka Tunggal Ika. Keberagaman tersebut telah diakomodasi dalam Undang-Undang Dasar Negara Republik Indonesia Tahun 1945 (UUD 1945). Dalam sejarah perjalanan bangsa, tidak dapat dimungkiri bahwa yang menjadi perekat dan pengikut kerujunan bangsa adalah nilai-nilai yang tumbuh, hidup, dan berkembang dalam kehidupan bermasyarakat. Nilai-nilai itu telah menjadi kekuatan pendorong untuk mencapai tujuan yang dicita-citakan. Kristalisasi nilai-nilai tersebut, tidak lain adalah sila-sila yang terkandung dalam pancasila. ${ }^{1}$

Pancasila telah membimbimbing kehidupan lahir batin yang makin baik di dalam masyarakat Indonesia. Pancasila sebagaimana termaktub pada Pembukaan UUD 1945 telah diterima dan ditetapkan sebagai dasar negara. Di dalam pancasila itulah tercantum kepribadian dan pandangan

\footnotetext{
${ }^{1}$ Sekretariat Jenderal MPR RI, 2012, Presiden Bicara Pancasila, Jakarta: Sekretariat Jenderal MPR RI, hlm, 27.
}

p-ISSN 2354-5976, e-ISSN 2580-7382

https://journal.uniku.ac.id/index.php/unifikasi

hidup bangsa yang telah diuji kebenaran dan keampuhannya, sehingga tidak ada satu kekuatan manapun juga yang mampu memisahkan Pancasila dari kehidupan bangsa Indonesia. Pancasila adalah fitrah (bawaan dasar) yang tak mungkin dilepaskan dari bangsa ini. Hasil penggalian atas nilai-nilai budaya bangsa yang antara lain, dilakukan oleh Bung Karno yang kemudian dipidatokannya pada tanggal 1 Juni 1945 di depan BPUPKI menunjukkan bahwa sejak berabad-abad yang lalu nenek moyang kita sudah hidup mendarah daging dengan nilainilai Pancasila, meskipun istilah Pancasila itu sendiri baru lahir kemudian sebagai nama. Bung karno menyatakan bahwa sila-sila itu digali dari budaya bangsa kita yang sudah

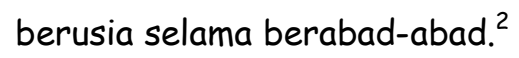

Bung Karno sendiri menyatakan bahwa beliau penggali Pancasila yang sudah hidup di masyakat. Oleh karena itu, harus dihindari klaim-klaim bahwa Pancasila buah karya seseorang atau kelompok tertentu, karena jika hal itu dilakukan tidak menutup kemungkinan akan menimbulkan polarisasi politik yang tajam di kalangan masyarakat dan bisa menimbulkan perpecahan. Sebaliknya harus ditumbuhkembangkan pemahaman, penghayatan, dan pengalaman Pancasila dalam semua segi kehidupan bangsa. Sebagai ideologi terbuka, Pancasila mengandung nilainilai dasar seperti cita-cita, tujuan, dan nilainilai instrumental yang merupakan arahan, kebijkan, strategi, sasaran dan sebagainya yang dapat disesuaikan dengan tuntutan zaman. Nilai-nilai dasar tidak boleh berubah, yang dapat berubah adalah nilai-nilai instrumental yang merupakan pengalaman,

\footnotetext{
2 Mahfud MD, 2012, Pancasila Memang Sakti, Jakarta: Sekretariat Jenderal MPR RI, hlm. 71.
} 
UNIFIKASI : Jurnal IImu Hukum, Volume 05 Nomor 01, Januari 2018

pengembangan, dan pengayaan nilai-nilai dasar. ${ }^{3}$

Dalam memberi dasar pemikiran pelaksanaan Pancasila formal yang merupakan pengertian umum abstrak atau umum universal, Notonegoro juga mengemukakan transformasi pengertian yang umum abstrak ke dalam bentuk dan isi pengertian yang umum kolektif dan pengertian yang khusus konkret. Notonegoro menyebut kedua bentuk transformasi itu dengan istilah subyektivikasi obyektif dan subyektivikasi subyektif. Subyektivikasi artinya pengalihan hubungan kesesuaian menjadi rumusan kelayakan atau moral. Hubungan kesesuaian adalah hubungan negara RI sebagai pendukung hubungan dan Tuhan, manusia, satu, rakyat dan adil sebagai pangkal atau ukuran hubungan. Notonegoro berpendapat rumus subyektivikasi obyektif (pedoman bagi moral negara) adalah: ${ }^{4}$ Sila pertama: Hakikat Negara adalah untuk memiliki sifat-sifat dan keadaan-keadaan berperi-Ketuhanan Yang Maha Esa); Sila kedua: Hakikat Negara adalah untuk memiliki sifat-sifat dan keadaan-keadaan berperikemanusiaan yang berperikeadilan dan berperikeadaban; Sila ketiga: Hakikat Negara adalah untuk memiliki sifat-sifat dan keadaan-keadaan berperi-Kesatuan dengan inti peri-kebangsaan; Sila keempat: Hakikat Negara adalah untuk memiliki sifat-sifat dan keadaan-keadaan berperikerakyatan yang dipimpin oleh hikmat kebijaksanaan dalam permusyawaratan/perwakilan; dan Sila kelima: Hakikat Negara adalah untuk memiliki sifat-sifat dan keadaan-keadaan berperikeadilan sosial bagi seluruh rakyat Indonesia.

${ }^{3}$ A. M Fatwa, 2010, Pancasila Karya Bersama Milik Bangsa, Bukan Hak Paten Suatu Golongan, Jakarta: The Fatwa Centre, hlm. 11.

${ }^{4}$ Notonegoro, 1980, Beberapa Hal Mengenai Filsafah Pancasila, Jakarta: Pantjoran Tujuh, hlm. 26.
p-ISSN 2354-5976, e-ISSN 2580-7382

https://journal.uniku.ac.id/index.php/unifikasi

Nilai-nilai yang terangkum dalam ideologi Pancasila ini kemudian terkikis dalam perkembangan zaman. Ideologi Pancasila yang didefinisikan Notonegoro menjadi hilang dalam kehidupan berbangsa dan bernegara kita secara perlahan dalam keseharian warga negara. Hal ini tidak lepas dari banyak ideologi selain Pancasila yang hadir di era reformasi. Padahal nilai-nilai Pancasila sudah mengakar dalam sejarah kehidupan Indonesia. Ideologi Pancasila menjadi nilainilai hidup bangsa Indonesia dalam bidang ketuhanan, budaya, politik dan sosial ekonomi yang mewarnai kehidupan bangsa Indonesia sejak zaman kuno dalam kelompok-kelompok kerajaan telah mengalami transformasi yang semakin lama semakin terintegrasi dalam kehidupan bangsa. $^{5}$ Kehidupan bangsa itu secara lambat laun diidentifikasi oleh tokohtokoh masyarakat sehingga menjadi kesadaran efektif yang menggerakkan mereka keluar dari himpitan-himpitan yang tidak wajar dari sistem penjajahan yang semakin lama semakin efektif.

Di era Reformasi saat ini, kehidupan bangsa dan negara kita kehilangan arah pembangunan nasional. Menjadi ironi karena pada hakikatnya pembangunan nasional kita berlandaskan pada lima landasan: 1) Pancasila sebagai landasan idiil; 2) UUD 1945 sebagai landasan konstitusional; 3) Wawasan Nusantara sebagai landasan visional; 4) Ketahanan Nasional sebagai landasan konsepsional; dan 5) Undang-undang sebagai landasan operasional. Lima landasan tersebut telah mengkristal dan menjadi komitmen bangsa sebagai paradigma pembangunan nasional. Keseluruhan landasan ini merupakan satu kesatuan yang utuh dan tidak terpisahkan satu sama lain, serta mengisi

${ }^{5}$ Ibid. 
UNIFIKASI : Jurnal IImu Hukum, Volume 05 Nomor 01, Januari 2018

landasan berpikir visi dan misi dalam pembangunan nasional. Tujuan dari penerapan lima landasan tersebut adalah lahirnya Indonesia yang berdaulat

Kedaulatan negara ini erat kaitannya dengan ideologi dan ketahanan nasional. Salah satu bentuk ketahanan nasional ini adalah bela negara, dimana untuk tetap tegaknya NKRI maka sudah barang tentu diperlukan upaya-upaya strategis dari warga negara untuk membelanya. Yang kemudian dikenal dengan Bela Negara, yang telah dirumuskan dalam pasal 27 ayat 3 UUD 1945 yakni setiap warga negara berhak dan wajib ikut serta dalam upaya Pembelaan Negara dan pasal 30 ayat 1 UUD 1945 yang menyatakan tiap-tiap Warga Negara berhak dan wajib ikut serta dalam usaha pertahankan dan keamanan Negara.

Salah satu wujud dari bela negara dalam usaha pertahankan dan keamanan Negara adalah mendahulukan kepentinagn yang terbaik bagi anak, atau biasanya yang disebut dengan perlindungan anak. Dengan melaksanakan perlindungan anak, maka akan terwujud tunas-tunas bangsa yang lebih baik dan tangguh jika sedari kecil sudah diberikan pemahaman tentang ideologi pancasila dan pemahaman bela negara. ${ }^{6}$ Namun hal ini akan berbanding terbalik jika perlindungan anak diabaikan oleh banyak pihak.

Anak merupakan sumber daya manusia yang berpotensi untuk meneruskan cita-cita bangsa Indonesia dimasa selanjutnya, anak memerlukan pembinaan dalam menjamin pertumbuhannya secara fisik, sosial, mental dengan cara bertahap dan seimbang. Sebagai sebuah pribadi yang sangat unik dan memiliki ciri yang khas, anak dapat bertindak

6 Laurensius Arliman S, Penyeban Anak Melakukan Pelecehan Seksual di Wilayah Hukum Kabupaten 50 Kota Provinsi Sumatera Barat, Lex Jurnalica, Vol. 13, Nomor 02, Agutus 2016, Jakarta, FH. Universitas Esa Unggul, hlm. 235.
p-ISSN 2354-5976, e-ISSN 2580-7382

https://journal.uniku.ac.id/index.php/unifikasi

berdasarkan perasaan, pikiran, dan kehendaknya sendiri, selain kehendaknya sendiri perbuatan atau perilaku anak juga dapat pula dipengaruhi dari lingkungan sekitarnya, seorang anak dapat melakukan tindakan atau perbuatan yang lepas kontrol, mereka dapat melakukan tindak pidana sehingga melanggar hukum. ${ }^{7}$

Sekarang banyak kasus dilalaikannya pelaksanaan perlindungan terhadap anak. Contohnya saja tentu kita masih mengingat ada anak di Bali yang dibunuh oleh ibu angkatnya pada tahun 2015, kemudian di tahun yang sama di Cibubur ada orang tua yang tega menelantarkan 5 (lima) orang anaknya walaupun satu rumah, bahkan orang tuanya juga didapati positif menggunakan narkoba, dan mau memberikan narkoba pada anaknya. Kemudian ada bayi yang dimutilasi pada tahun 2016 serta bahkan pada tahun yang sama banyak terungkap kasus prostitusi yang melibatkan anak perempuan di bawah umur dan terjadi baynak perkosaan dimana satu orang anak perempuan digilir oleh banyak laki (baik yang sudah dewasa atau anak laki-laki dibawah umur) sehingga presiden mengeluarkan Peraturan Pemerintah Pengganti Undang-Undang Nomor 1 Tahun 2016 tentang Kebiri perubahan ketiga atas UU Perlindungan Anak (Perppu Kebiri). Namun dengan adanya pengaturan anak yang lebih lanjut dikeluarkan oleh Presiden Joko Widodo (Jokowi), ternyata perlindungan terhadap anak masih saja tetap tidak bisa terlaksanakan, karena di awal tahun 2017 pihak penegak hukum membongkar kasus prostitusi online yang melibatkan anak lakilaki dibawah umur yang dijual kepada pria dewasa yang tidak bertanggung jawab.

\footnotetext{
7 Komar Hidayat, Yunusrul Zen dan Diding Rahmat, Analisis Yuridis Terhadap Kebijakan Diversi Pemerintah Daerah Dalam Perlindungan Anak Di Kabupaten Kuningan, Jurnal Unifikasi, Vol. 04, Nomor 02, Juli 2017, Kuningan, FH. Uniku, hlm. 87.
} 
UNIFIKASI : Jurnal IImu Hukum, Volume 05 Nomor 01, Januari 2018

Sehingga menjadi pertanyaan, apakah kita siap mewujudkan perlindungan anak sebagai generasi penerus bangsa, yang nantinya menjadi pelindung bangsa ini kelak, untuk mempertahankan kedaulatan dan juga keutuhan bangsa ini, jika hak-hak anak sudah dilalaikan dari sekarang dan apakah pandangan kita terhadap Ideologi Pancasila mulai runtuh, sehingga dengan mudah hak-hak anak terabaikan.

\section{RUMUSAN MASALAH}

Atas pemaparan penulis diatas, maka rumusan masalah dalam penulisan penelitian ini adalah sebagai berikut: 1) Bagaimana kedudukan pancasila sebagai ideology Indonesia? dan 2) bagaimana mewujudkan perlindungan anak sebagai cita-cita bela negara

\section{METODE PENELITIAN}

Penelitian hukum yang dilaksanakan merupakan penelitian hukum normatif dengan metode pendekatan yuridis normatif yang menitik beratkan penggunaan bahan atau meteri penelitian data sekunder dengan di dukung oleh data kepustakaan. Di samping itu, penelitian ini juga menggunakan pendekatan perundang-undangan (statute approach), pendekatan historis (historical approach), dan pendekatan perbandingan (comparative approach). Dlihat dari spesifikasinya, penelitian ini termasuk deskriptif analitis yaitu penelitian yang menggabarkan dan menganalisis permasalahan yang berhubungan dengan penerapan ideologi Pancasila untuk mewujudkan perlindungan anak-anak sebagai cita-cita bela negara. Dalam penelitian ini, proses perolehan data untuk menunjang hasil penelitian dilakukan melalui tahapan studi kepustkaan (library research) dengan menggunakan data sekunder, yaitu mencoba untuk menemukan buku-buku, konsep-konsep, teori-teori dan pendapat para ahli serta
p-ISSN 2354-5976, e-ISSN 2580-7382

https://journal.uniku.ac.id/index.php/unifikasi

penemuan yang berhubungan erat dengan pokok permasalahan yang akan diteliti.

\section{PEMBAHASAN}

\section{Kedudukan Ideologi Pancasila Sebagai Landasan Negara}

Pancasila adalah dasar ideologi negara Republik Indonesia yang secara resmi disahkan oleh PPKI pada tanggal 18 Agustus 1945 dan tercantum dalam Pembukaan UUD 1945, diundangkan dalam Berita Republik Indonesia tahun II Nomor 7 bersama-sama dengan batang tubuh UUD 1945. Dalam perjalanan sejarah eksistensi Pancasila sebagai dasar ideologi negara Republik Indonesia mengalami berbagai macam interpretasi dan manipulasi politik sesuai dengan kepentingan penguasa demi kokoh dan tegaknya kekuasaan yang berlindung dibalik legitimasi ideologi negara pancasila. Dengan kata lain perkataan dalam kedudukan yang seperti ini Pancasila tidak lagi diletakan sebagai dasar ideologi serta pandangan hidup bangsa dan negara Indonesia melainkan direduksi, dibatasi dan dimanipulasi demi kepentigan politik penguasa pada saat itu. ${ }^{8}$ Tentu ini sangat bertentangan dengan citacita para pejuang bangsa, yang meletakkan Pancasila sebagai dasar ideologi. Maka dari itu harus ada pemikiran kita untuk tetap menguatakan Pancasila dalam kehidupan kita, sehingga Pancasila selalu dipandang sebagai ideologi negara kita.

Pancasila disebut sebagai padndangan hidup Bangsa Indonesia karena nilai-nilai yang terkandung dalam sila-sila tersebut dari waktu ke waktu dan secara tepat telah menjadi bagian yang tidak terpisahkan dari kehidupan bangsa Indonesia. Nilai-nilai yang dimaksud adalah nilai ketuhanan, nilai kemanusian, nilai persatuan, nilai kerakyatan,

\footnotetext{
8 Kaelan, 2010, Penddidikan Pancasila, Yogyakarta: Paradigma, hlm. 29.
} 
UNIFIKASI : Jurnal IImu Hukum, Volume 05 Nomor 01, Januari 2018

dan nilai keadilan sosial. Nilai-nilai Pancasila ini merupakan satu kesatuan yang bulat dan utuh, yang tersusun secara sistematishirarkis, artinya bahwa antara nilai yang satu dengan lainnya saling berhubungan, tidak boleh dipisah-pisahkan. ${ }^{9}$

Nilai ketuhanan terkandung dalam sila pertama, yaitu Ketuhanan Yang Maha Esa mengandung pengertian bahwa kita bangsa Indonesia percaya dan takwa kepada Tuhan Yang Maha Esa itu bersifat aktif, artinya kita harus selalu berusaha menjalankan segala perintah-Nya dan menjauhi segala laranganNya menurut ajaran agama dan kepercayaan masing-masing. Sila ini menjadi sumber utama nilai-nilai kehidupan bangsa Indonesia, yang menjiwai dan mendasari serta membimbing perwujudan sila kedua sampai dengan sila kelima, ${ }^{10}$ terutama didalam menjalankan perlindungan anak dalam rangka menyiapkan generasi penerus bangsa yang mau, ikhlas, setia dan rela membela NKRI.

Nilai kemanusian terkandung dalam sila kedua, yaitu Kemanusiaan Yang Adil dan Beradab yang berarti menjunjung tinggi nilainilai kemanusiaan, kesadaran sikap dan perbuatan manusia yang didasarkan kepada potensi budi nurani manusia dalam hubungannya dengan norma-norma dan kebudayaan umumnya, secara lain dapat dikatakan bahwa manusia bebas keinginannya, tetapi terikat pula oleh keterbatasan dan tanggungjawabnya kepada masyarakat dan Negara, dibatasi juga oleh lingkungannya. Kemanusiaan yang adil dan beradab bersumber pada ajaran Tuhan Yang Maha Esa, yaitu sesuai dengan kodrat manusia sebagai ciptaan-Nya. Maka dari itu perlakuan manusia terhadap sesamanya harus sesuai

\footnotetext{
${ }^{9}$ M. Hatta Ali, 2012, Landasan Filsofi Pancasila Dalam Berbangsa dan Bernegara Kesatuan Republik Indonesia, Jakarta: Sekretariat Jenderal MPR RI, hlm. 46.$$
10 \text { Ibid. }
$$

p-ISSN 2354-5976, e-ISSN 2580-7382

https://journal.uniku.ac.id/index.php/unifikasi

dengan nilai-nilai kemanusiaan dan fitrahnya, manusia harus hormat terhadap sesamanya, tidak memandang rendah atau merendahkan, karena dihdapan Tuhan status manusia adalah sama dan yang membedakan hanyalah ketakwaan terhadap Tuhan.

Nilai persatuan yang terkandung dalam sila ketiga Pancasila adalah bahwa persatuan bangsa yang mendiami wilayah Indonesia. Bangsa Indonesia menempatkan persatuan, kesatuan, serta kepentingan dan keselamatan bangsa dan Negara di atas kepentingan pribadi atau golongan dengan tujuan memajukan kesejahteraan umum dan mencerdaskan kehidupan bangsa serta ikut mewujudkan perdamaian dunia yang abadi. Persatuan Indonesia merupakan perwujudan dari nilai ketuhanan dan nilai kemanusiaan yang membina tumbuhnya persatuan dan kesatuan bangsa Indonesia, seperti dilukiskan dalam lambang Garuda Pancasila dengan semboyan Bhineka Tunggal Ika, yang mengandung makna berbeda-beda tetap satu jua. ${ }^{11}$

Nilai kerakyatan terkandung dalam sila keempat Pancasila menunjukkan makna bahwa kekuasaan tertinggi berada di tangan rakyat yang disebut pula sebagai kedaulatan rakyat, artinya rakyat yang berdaulat atau berkuasa dan menentukan atau diistilahkan dengan demokrasi, yang berarti rakyat yang memerintah atau pemerintahan dengan mengikutsertakan rakyat. Kerakyatan yang Dipimpin oleh Hikmat Kebijaksanaan dan Permusyawaratan/Perwakilan, artinya rakyat dalam menjalankan kekuasaannya atau kekuasaan yang dijalankan dengan mengatasnamakan rakyat dilakukan melalui sistem perwakilan, dan keputusan-keputusan yang diambil oleh pikiran yang sehat serta tanggungjawab, baik kepada Tuhan Yang

\footnotetext{
${ }^{11}$ Kaelan, Op.cit.
} 
UNIFIKASI : Jurnal IImu Hukum, Volume 05 Nomor 01, Januari 2018

Maha Esa, maupun kepada rakyat yang telah diwakilkan (rakyat banyak) yang selalu mempertimbangkan persatuan dan kesatuan bangsa.

Nilai keadilan sosial yang terkadnung dalam sila kelima Pancasila berarti bahwa setiap rakyat Indonesia mendapat perlakuan yang adil dalam bidang hukum, politik, ekonomi, sosial budaya, dan pertahanan keamanan. Makna keadilan sosial disini mencakup pula pengertian adil dan makmur. Kehidupan manusia meliputi kehidupan jasmani dan rohani, maka keadilan pun meliputi keadilan di dalam pemenuhan tuntutan hakiki bagi kehidupan jasmani dan rohani atau materiul dan spritual manusia, yaitu bagi seluruh rakyat Indonesia secara merata (terkhushusnya anak), berdasarkan atas asas kekeluargaan. ${ }^{12}$ Sila keadilan sosial ini merupakan tujuan dan 4 (empat) sila yang mendahului, sebagai tujuan bangsa Indonesia dalam bernegara, yang perwujudannya ialah tata masyarakat adil dan makmur berdasarkan Pancasila.

Nilai-nilai luhur yang terkandung dalam Pancasila sebagai ideologi bangsa seharusnya bukan hanya untuk diketahui saja tetapi harus dimengerti yang kemudian diamalkan dikehidupan sehari-hari dalam berabagai aspek kehidupan. Perlakuan yang sama terhadap setiap warga Negara Indonesia (terkhususnya terhadap perlindungan anak) dalam bidang hukum, juga harus menerapakan nilai-nilai luhur yang terkandung dalam Pancasila, yaitu keadilan begai seluruh rakyat Indonesia yang tidak membeda-bedakan dari berbagai aspek kehidupan, keputusan yang diambil secara musyawarah yang didasarkan oleh pikiran yang sehat, persatuan dan kesatuan bangsa yang tidak mementingkan pribadi dan

${ }^{12}$ M. Hatta Ali, Op.cit.
p-ISSN 2354-5976, e-ISSN 2580-7382

https://journal.uniku.ac.id/index.php/unifikasi

golongan, perlakuan terhadap setiap anak manusia dari kecil hingga dewasa secara manusiawi dan tidak merendahkan, serta tanggung jawab terhadap Tuhan Yang Maha Esa.

\section{Perlindungan Anak Sebagai Cita-Cita Bela Negara}

Upaya pertahanan negara harus didasarkan pada kesadaran akan hak dan kewajiban warga negara, serta keyakinan pada kekuatan sendiri. Hal ini juga tercantum dalam Pasal 1 Ayat 1 Undang-Undang Republik Indonesia Nomor 3 tahun 2002 tentang Pertahanan Negara pada menyatakan bahwa Pertahanan keamanan Negara adalah segala usaha untuk mempertahankan negara, keutuhan wilayah NKRI, dan keselamatan bangsa dari ancaman dan gangguan terhadap keutuhan bangsa dan negara. Bangsa Indonesia cinta perdamaian, tetapi lebih cinta kemerdekaan dan kedaulatan. Alinea pertama Pembukaan UUD 1945 menyatakan, "Bahwa sesungguhnya kemerdekaan itu ialah hak segala bangsa dan oleh sebab itu, maka penjajahan di atas dunia harus dihapuskan. Karena tidak sesuai dengan perikemanusiaan dan perikeadilan". Penyelesaian pertikaian atau konflik antarbangsa pun harus diselesaikan melalui cara-cara damai. Bagi bangsa Indonesia, perang harus dihindari. Perang merupakan jalan terakhir dan dilakukan jika semua usaha-usaha dan penyelesaian secara damai tidak berhasil. Indonesia menentang segala bentuk penjajahan dan menganut politik bebas aktif. Prinsip ini merupakan pelaksanaan dari bunyi alinea pertama Pembukaan Undang-Undang Dasar Negara Republik Indonesia Tahun 1945.

Ada beberapa dasar hukum dan peraturan tentang wajib bela Negara, yaitu sebagai berikut: 
UNIFIKASI : Jurnal Ilmu Hukum,

a) Tap MPR Nomor VI Tahun 1973 tentang konsep Wawasan Nusantara dan Keamanan Nasional;

b) Undang-Undang Nomor 29 tahun 1954 tentang Pokok-Pokok Perlawanan Rakyat:

c) Undang-Undang Nomor 20 tahun 1982 tentang Ketentuan Pokok Hankam Negara RI, diubah oleh Undang-Undang Republik Indonesia Nomor 1 Tahun 1988;

d) Tap MPR No.VI Tahun 2000 tentang Pemisahan TNI dengan POLRI;

e) Tap MPR No.VII Tahun 2000 tentang Peranan TNI dan POLRI;

f) Amandemen Undang-Undang Dasar Negara Republik Indonesia Tahun 1945 Pasal 30 Ayat (1) dan (2) yang menyatakan "bahwa tiap warga negara berhak dan wajib ikut serta dalam usaha pertahanan dan keamanan Negara yang dilaksanakan melalui sistem pertahanan dan keamanan rakyat semesta oleh TNI dan Kepolisian sebagai komponen utama, dan rakyat sebagai kekuatan pendukung". Ada pula pada Pasal 27 Ayat (3): "Setiap warga negara berhak dan wajib ikut serta dalam upaya pembelaaan negara";

g) Undang-Undang Nomor 39 Tahun 1999 Tentang Hak Asasi Manusia Pasal 6B yang menyatakan Setiap Warga Negara wajib ikut serta dalam upaya pembelaan Negara, sesuai dengan ketentuan yang berlaku";

h) Undang-Undang Republik Indonesia Nomor 3 Tahun 2002 tentang Pertahanan Negara, pasal 9 Ayat 1: "Setiap warga negara berhak dan wajib ikut serta dalam upaya bela negara yang diwujudkan dalam penyelenggaraan pertahanan negara"; Ayat (2): "Keikutsertaan warga negara dalam upaya bela negara, sebagaimana dimaksud ayat 1 diselenggarakan melalui: a. pendidikan Kewarganegaraan, b. pelatihan dasar kemiliteran, c. pengabdian sebagai
p-ISSN 2354-5976, e-ISSN 2580-7382

https://journal.uniku.ac.id/index.php/unifikasi

prajurit TNI secara sukarela atau wajib, dan d. pengabdian sesuai dengan profesi.

Bela Negara adalah sikap dan tindakan warga negara yang teratur menyeluruh terpadu dan berlanjut yang dilandasi oleh kecintaan pada tanah air, kesadaran berbangsa dan bernegara Indonesia serta keyakinan akan kesaktian Pancasila sebagai Ideologi Negara dan kerelaan untuk berkorban guna meniadakan setiap ancaman baik dari luar negeri maupun dalam negeri yang mmebahayakan kemedekaan dan kedaulatan negara, kesatuan dan persatuan bangsa, keutuhan wilayah dan yurisdiksi nasional serta nilai-nilai Pancasila dan UUD RI 1945. Lima dasar bela negara sebagaimana disampaikan diatas yakni: ${ }^{13}$

a) Cinta Tanah Air. Yang dimaksud tanah air ialah ruang wilayah Negara baik secara geografis, maupun tata nilai dan tata kehidupan masyarakat. yang telah memberikan sumber kehidupan dan penghidupan, sejak manusia lahir sampai pada akhir hayatnya. Dengan demikian setiap warga Negara harus mencintai Tanah Air sebagai ruang hidup dalam menjalankan kehidupannya. Dalam kenyataanya ruang hidup suatu bangsa tidak pernah lepas dari segala bentuk ancaman, tantangan, hambatan, gangguan dalam negeri maupun yang datangnya dari luar negeri. Sehingga setiap warga Negara harus selalu siapuntuk mempertahankan kelangsungan hidup bangsa dan Negara Indonesia;

b) Kesadaran Berbangsa dan Bernegara. Adalah suatu sikap dan tingkah laku yang sesuai dengan kepribadian bangsa dan

13 Deden Koswara, Implementasi Nilai-Nilai Belanegara Dalam Kehidupan Bermasyarakat, Berbangsa Dan Bernegara Bagi Tegaknya Keutuhan NKRI, Jurnal Islamica, Volu. 2 Nomor 1, 2014, Bandung: STAI Siliwangi, hlm. 52. 
UNIFIKASI : Jurnal Ilmu Hukum,

selalu mengkaitkan dirinya dengan citacita dan tujuan hidup bangsanya, tumbuh rasa kesatuan, Persatuan Bangsa Indonesia, memiliki jiwa besar dan patriotisme serta memiliki kesadaran atas tanggungjawab sebagai Warga Negara.

c) Yakin akan Pancasila Sebagai Idiologi Negara dan Pandangan Hidup Bangsa. Pancasila telah disepakati sebagai falsafah dan Idiologi Bangsa dan Negara dalam penyelenggaraan kehidupan berbangsa bernegara guna tercapainya tujuan nasional, juga Pancasila merupakan sumber hukum sekaligus sebagai kerangka acuan NKRI karena Pancasila telah dapat mempersatukan Rakyat Indonesia yang terdiri dari beranekaragam agama, suku bangsa, bahsa, asal-usul keturunan. Dalam perjalanan sejarah bangsa, telah berkalikali dipecah oleh penjajah maupun oleh pihak yang tidak menyukai Pancasila, namun Bangsa Indonesia sampai saat ini masih tetap utuh sebagai bangsa yang bersatu dan kuat dalam menuju masyarakat yang adil dan makmur, nilainilai Pancasila dapat pula dipergunakan dalam penyelesaian konflik, mematahkan setiap ancaman, tantangan, hambatan dan gangguan ( $A T H G$ ) terhadap keutuhan bangsa masih dapat kita atasi bersama berdasarkan kaidah Demokrasi Pancasila, yang menjunjung tinggi sifat kekeluargaan dan gotong royong:

d) Rela Berkorban untuk Bangsa dan Negara. Dalam melaksanakan kegiatan bernegara, seluruh warga Negara di tuntut rela berkorban dengan mendahulukan kepentingan umum daripada kepentingan pribadi/golongan. Hal ini diperlukan, karena tidak mungkin cita-cita bangsa dapat diraih apabila setiap warga Negara Indonesia hanya mendahulukan kepentingan pribadi/golongan saja tanpa
p-ISSN 2354-5976, e-ISSN 2580-7382

https://journal.uniku.ac.id/index.php/unifikasi

lebih mementingkan kepentingan Bangsa dan Negara;

e) Memiliki Kemampuan Awal Bela Negara. Secara psikis, setiap warga Negara dituntut untuk memiliki sikap perilaku dispilin, ulet, kerja keras, taat aturan, percaya pada kemampuan sendiri, tahan uji, pantang menyerah, sedangkan secara fisik (jasmani) memiliki kesehatan prima dan tangkas hal tersebut sejalan dengan pepatah kuno yaitu dalam badan sehat terdapat jiwa yang kuat. ${ }^{14}$

Nilai, keyakinan, dan aturan kedisiplinan yang ada dalam ideologi Pancasila harus ditanamkan kepada anak sejak dini. Tentunya, penanaman tersebut sejalan dengan perkembangan kognitif anak dan dilaksanakan secara terus-menerus dengan konsisten. Dengan demikian, nilai-nilai yang diajarkan akan berbuah menjadi perilaku dan kebiasaan dalam kehidupan mereka seharihari. Salah satu cita-cita bela negara adalah perlindungan anak. ${ }^{15}$

Tanggal 26 Desember 2015, Komisi Perlindungan Anak Indonesia (KPAI) dan Kementerian Pertahanan menyelenggarakan program Bela Negara untuk anak-anak. Tujuannya adalah untuk penanaman nilai untuk cinta Tanah Air yang penyelenggaraannya disesuaikan dengan perkembangan tumbuh kembang anak. Kerja bareng ini berangkat dari rasa keprihatinan atas hilangnya rasa cinta terhadap bangsa dan negara dan semakin mencekamnya perlindungan anak di masyarakat. Rakyat Indonesia saat ini merasa kondisi bangsa dan negara semakin hari semakin jauh dari cita-cita luhur para pendiri

\section{${ }^{14}$ Ibid.}

15 Laurensius Arliman S, Peran Pemerintah Daerah Dalam Perlindungan Hak Anak Berdasarkan Undang-Undang Nomor 35 Tahun 2014 Tentang Perlindungan Anak, Jurnal Yustisia, Volume. 22 Nomor 1, 2015, Padang: Universitas Andalas, hlm. 89-91. 
UNIFIKASI : Jurnal IImu Hukum, Volume 05 Nomor 01, Januari 2018

bangsa (Republika; 2015). Bela Negara untuk anak adalah segmented program yang tujuannya sangat mulia. Di dalamnya ada semangat perlindungan anak dari bahaya cara pandang, ideologi, dan perspektif yang menjauhkan anak dari keutuhan negara dan bangsanya sendiri. Ini juga menjadi implementasi lima pilar perlindungan anak, di antaranya adalah pemerintah dan negara. Keduanya hadir untuk melindungi anak-anak kita dari komplek sitas ancaman, gangguan, dan bahaya di sekitar kehidupan anak.

Daya tangkal bangsa dalam menghadapi kompleksitas ancaman guna mewujudkan ketahanan nasional yang tangguh harus dibangun. Untuk itu dibutuhkan penanaman kesadaran bela negara sebagai bentuk revolusi mental sedini mungkin. Upaya menumbuhkan rasa kecintaan terhadap tanah air, sadar berbangsa dan bernegara, setia kepada ideologi Pancasila, rela berkorban bagi bangsa dan negara serta memiliki kemampuan dasar bela negara harus sedini mungkin dan dimulai dari dalam keluarga. Keikutsertaan seluruh elemen bangsa sangat penting terlebih-lebih sosok ibu dan keluarga yang sangat berperan besar untuk membentuk karakter anak yang tangguh sejak usia dini. Melalui bela negara akan terbangun karakter disiplin, optimisme, kerjasama dan kepemimpinan guna turut menjamin kelangsungan hidup bangsa dan negara. ${ }^{16}$

Kesadaran Bela Negara sangat dibutuhkan untuk anak-anak kita pada saat ini. Tentunya, hal ini tidak lepas dari keinginan kita untuk menjaga keutuhan

16 Ryamizard Ryacudu, 2015, Tanamkan Nilai Kebangsaan dan Cinta Tanah Air Sejak Dini, Kementerian Pertahanan dan Kemeterian Pemberdayaan Perempuan Dan Perlindungan Anak Republik Indonesia, http://www.kemenpppa.go.id/index.php/page/read/29/1 62/press-release-tanamkan-nilai-kebangsaan-dan-cintatanah-air-sejak-dini, diakes pada tanggal 5 Desember 2017.
p-ISSN 2354-5976, e-ISSN 2580-7382

https://journal.uniku.ac.id/index.php/unifikasi

bangsa dan negara pada masa yang akan datang. Bukankah nasib negara kita di masa depan bergantung ba gaimana kita mendidik anak-anak pada saat ini? Lebih dari itu, kita ingin membangun daya tangkal dalam menghadapi kompleksitas ancaman guna mewujudkan ketahanan nasional yang tangguh. Melalui Bela Negara diharapkan akan terbangun generasi yang memiliki karakter disiplin, optimisme, kerja sama, dan kepemimpinan yang sudah barang tentu menjamin kelangsungan hidup bangsa dan negara kita. ${ }^{17}$ Penanaman nilai cinta Tanah Air sejak dini, artinya kita membangun rasa nasionalisme dan kebangsaan di generasi muda. Ini menjadi upaya konkret untuk menentukan sikap dalam konteks mempertahankan Pancasila dan keutuhan NKRI.

Salah satu cita-cita bela negara untuk mempertahan keutuhan NKRI adalah melaksanakan perlindungan anak yang bekelanjutan. Penanaman pemahaman perlindungan anak berkelanjutan sangatlah perlu diajarkan secara dini kepada masyarakat. Karena dengan adanya penanaman pemahaman perlindungan anak berkelanjutan membuat perlindungan ini tidak berhenti ketika ada kasus-kasus anak yang sedang hangat diperbincangkan, lebih jauh dari itu hal ini berpengaruh pada implementasi undang-undang perlindungan anak yang ada bisa dilaksanakan oleh setiap orang, aparat penegak hukum, dan pihakpihak terkait yang disebutkan dalam undangundang perlindungan anak secara berkelanjutan atau the best life to children. ${ }^{18}$

${ }^{17}$ Republika, Bela Negera di Usia Dini, Jakarta, Republika, 2015, h/m. 9.

${ }^{18}$ Laurensius Arliman S, Partisipasi Masyarakat Di Dalam Perlindungan Anak Yang Berkelanjutan Sebagai Bentuk Kesadaran Hukum, Padjadjaran Jurnal Ilmu 
UNIFIKASI : Jurnal IImu Hukum, Volume 05 Nomor 01, Januari 2018

Perserikatan Bangsa-Bangsa (PBB) telah mengesahkan Deklarasi tentang HakHak Anak. Dalam Mukadimah Deklarasi ini, tersirat bahwa umat manusia berkewajiban memberikan yang terbaik bagi anak-anak. Hal ini merupakan penanaman prinsip perlindungan anak berkelnjutan yang sudah lama digagaskan secara universal, dan harusnya berlaku di seluruh dunia untuk penegakan hukum perlindungan anak dan hal ini juga bisa diterapkan dalam rangka bela negara terhadap perlindunga anak. Deklarasi ini memuat 10 (sepuluh) asas tentang hak-hak anak, yaitu: ${ }^{19}$

1) Anak berhak menikmati semua hak-haknya sesuai dengan ketentuan yang terkandung dalam deklarasi ini. Setiap anak tanpa pengecualian harus dijamin hak-haknya tanpa membedakan suku bangsa, warna kulit, jenis kelamin, bahasa, agama, pandangan politik, kebangsaan, tingkatan sosial, kaya miskin, kelahiran atau status lain, baik yang ada pada dirinya maupun pada keluarganya;

2) Anak berhak memperoleh perlindungan khusus, dan harus memperoleh kesempatan yang dijamin oleh hukum, dan sarana lain, agar menjadikannya mampu untuk mengembangkan diri secara fisik, kejiwaan, dan moral, mampu untuk mengembangkan diri secara fisik, kejiwaan, moral, spiritual, dan kemasyarakatan dalam situasi yang sehat, normal sesuai dengan kebebasan, dan harkatnya. Penuangan tujuan itu ke dalam hukum, kepentingan terbaik atas diri anak harus merupakan pertimbangan utama dalam bela negara;

Hukum, Vol, 3 Nomor 2, 2016, Bandung: Universitas Padjadjaran, hlm. 71.

19 Maidin Gultom, 2014, Perlindungan Hukum Terhadap Anak Dalam Sistem Peradilan Pidana Anak Di Indonesia, Bandung: Refika Aditama, hlm. 74.
p-ISSN 2354-5976, e-ISSN 2580-7382

https://journal.uniku.ac.id/index.php/unifikasi

3) Anak sejak dilahirkan berhak akan nama, dan kebangsaan;

4) Anak berhak, dan harus dijamin secara kemasyarakatan untuk tumbuh, dan kembang secara sehat. Untuk ini baik sebelum maupun setelah kelahirannya harus ada perawatan, dan perlindungan khusus bagi anak, dan ibunya. Anak berhak mendapat gizi yang cukup, perumahan rekreasi, dan pelayanan kesehatan;

5) Anak yang cacat fisik, mental, dan lemah kedudukan sosialnya akibat keadaan tertentu harus memperoleh pendidikan, perawatan, dan perlakuan khusus;

6) Agar kepribadian anak tumbuh secara maksimal, dan harmonis, ia memerlukan kasih sayang, dan pengertian. Sedapat mungkin ia harus dibesarkan di bawah asuhan, dan tanggungjawab orang tuanya sendiri, dan bagaimanapun harus diusahakan agar tetap berada dalam suasana yang penuh kasih sayang, sehat jasmani, dan rohani. Anak di bawah usia 5 (lima) tahun tidak dibenarkan terpisah dari ibunya. Masyarakat, dan pemerintah yang berwenang berkewajiban memberikan perawatan khusus kepada anak yang tidak memiliki keluarga, dan kepada anak yang tidak mampu. Diharapkan agar pemerintah atau pihak lain memberikan bantuan pembiayaan bagi anak-anak yang berasal dari keluarga besar;

7) Anak berhak mendapat pendidikan wajib secara gratis sekurang-kurangnya pada tingkat pendidikan dasar. Mereka harus mendapat perlindungan yang dapat meningkatkan pengetahuan umumnya, dan yang memungkinkan atas dasar kesempatan yang sama untuk mengembangkan kemampuannya, pendapat pribadinya, dan persaan tanggungjawab moral, dan sosialnya, sehingga mereka dapat menjadi anggota masyarakat yang 
UNIFIKASI : Jurnal Ilmu Hukum,

Volume 05 Nomor 01, Januari 2018

berguna. Kepentingan anak haruslah dijadikan pedoman oleh mereka yang bertanggungjawab terhadap pendidikan, dan bimbingan anak yang bersangkutan: pertama-tama tanggung jawab tersebut terletak pada orang tua mereka. Anak harus mempunyai kesempatan yang leluasa untuk bermain, dan berekreasi yang diarahkan untuk tujuan pendidikan, masyarakat, dan pemerintah yang berwenang harus berusaha meningkatkan pelaksanaan hak ini;

8) Dalam keadaan apapun anak harus didahulukan dalam menerima perlindungan, dan pertolongan;

9) Anak harus dilindungi dari segala bentuk kealapaan, kekerasan, dan eksploitasi. Ia tidak boleh dijadikan subjek perdagangan. Anak tidak boleh bekerja sebelum usia tertentu, ia tidak boleh dilibatkan dalam pekerjaan yang dapat merugikan kesehatan atau pendidikannya, maupun yang dapat mempengaruhi perkembangan tubuh, jiwa, dan akhlaknya;

10) Anak harus dilindungi dari perbuatan yang mengarah ke dalam bentuk diskriminasi sosial, agama maupun bentuk-bentuk diskriminasi lainnya. Mereka harus dibesarkan di dalam semangat penuh pengertian toleransi, dan persahabatan antarbangsa, perdamaian, serta persaudaraan semesta dengan penuh kesadaran bahwa tenaga, dan bakatnya harus diabadikan kepada sesama manusia. $^{20}$

\section{SIMPULAN}

Berdasarkan uraian tersebut dapat disimpulkan sebagai berikut Pancasila adalah Ideologi dan sumber dari segala pembentukan pertiran perundnag-undangan yang ada di

\footnotetext{
${ }^{20}$ Ibid.
}

p-ISSN 2354-5976, e-ISSN 2580-7382

https://journal.uniku.ac.id/index.php/unifikasi

Indonesia. UUD 1945 dan UU Bela Negara mengisyaratkan agar setiap masyarakat melaksanakan pertahana negara, demi menjaga keutuhan NKRI. Bela Negara adalah sikap dan perilaku warga Negara yang teratur, menyeluruh, terpadu dan berlanjut yang dilandasi oleh kecintaan pada tanah air, kesadaran berbangsa dan bernegara serta keyakinan akan pancasila sebagai ideologi Negara guna menghadapi ancaman baik yang berasal dari luar maupun dari dalam negeri yang membahayakan dan mengancam kedaulatan baik kedaulatan di bidang Ideologi, Politik, Ekonomi, Sosial, Budaya, Pertahanan dan Keamanan Negara. Program Bela Negara terhadap perlindungan anak. Tujuannya adalah penanaman nilai untuk cinta Tanah Air yang penyelenggaraannya disesuaikan dengan perkembangan tumbuh kembang anak. Melalui bela negara akan terbangun karakter disiplin, optimisme, kerjasama dan kepemimpinan guna turut menjamin kelangsungan hidup bangsa dan negara. Banyak alasan mengapa kita sebagai warga negara wajib mengupayakan untuk membela negara. Oleh dari itu, kita sebagai generasi penerus mempunyai kewajiban untuk memberi contoh bela negara, sesuai dengan arti atau pengertian bela negara indonesia. Hal itu diwujdukan dalam bentuk perlindungan anak berkelanjutan. Dengan adanya perlindungan anak berkelanjutan, akan menciptakan generasi penerus bangsa yang paham dengan mempertahankan dan membela NKRI yang menanamkan nilai-nilai falsafah pancasila. Ada 10 (sepuluh) poin yang bisa diterapkan di dalam menerapakan perlindungan anak yang berkelanjutan ini.

\section{SARAN}

Berdasarkan uraia diatas makan dapat diberikan beberapa saran sebagai berikut: a) dengan semnagat Pancasila seharusnya menjadi modal bagi setiap 
UNIFIKASI : Jurnal IImu Hukum, Volume 05 Nomor 01, Januari 2018

masyarakat dalam memberikan perlinudngan anak; b) dengan adanya kegiatan bela negara seharusnnya mendorong masyarakat untuk bersikap responsif di dalam memeberikan perlindungan anak; c) pemerintah harus memberikan banyak sosialisasi bagaimana seharusnya perlindungan anak yang baik dan berkelanjutan, karena anak merupakan generasi penerus bangsa, dan yang akan melanjutkan cita-cita luhur dari Pancasila.

\section{DAFTAR PUSTAKA}

Ali, M. Hatta. 2012. Landasan Filsofi Pancasila Dalam Berbangsa dan Bernegara Kesatuan Republik Indonesia, Jakarta: Sekretariat Jenderal MPR RI.

Arliman S, Laurensius. Peran Pemerintah Daerah Dalam Perlindungan Hak Anak Berdasarkan Undang-Undang Nomor 35 Tahun 2014 Tentang Perlindungan Anak, Jurnal Yustisia, Volu. 22 Nomor 1, 2015, Padang: Universitas Andalas.

Arliman S, Laurensius. Penyeban Anak Melakukan Pelecehan Seksual di Wilayah Hukum Kabupaten 50 Kota Provinsi Sumatera Barat, Lex Jurnalica, Vol. 13, Nomor 02, Agutus 2016, Jakarta, FH. Universitas Esa Unggul.

Arliman S, Laurensius. Partisipasi Masyarakat Di Dalam Perlindungan Anak Yang Berkelanjutan Sebagai Bentuk Kesadaran Hukum, Padjadjaran Jurnal Ilmu Hukum, Vol, 3 Nomor 2, 2016, Bandung: Universitas Padjadjaran.

Fatwa, A.M. 2010, Pancasila Karya Bersama Milik Bangsa, Bukan Hak Paten Suatu Golongan, Jakarta: The Fatwa Centre. Gultom, Maidin. 2014, Perlindungan Hukum Terhadap Anak Dalam Sistem Peradilan Pidana Anak Di Indonesia, Bandung: Refika Aditama.
p-ISSN 2354-5976, e-ISSN 2580-7382

https://journal.uniku.ac.id/index.php/unifikasi

Hidayat, Komar. Yunusrul Zen dan Diding Rahmat, Analisis Yuridis Terhadap Kebijakan Diversi Pemerintah Daerah Dalam Perlindungan Anak Di Kabupaten Kuningan, Jurnal Unifikasi, Vol. 04, Nomor 02, Juli 2017, Kuningan, FH. Uniku.

Kaelan, 2010. Penddidikan Pancasila, Yogyakarta: Paradigma.

Koswara, Deden. Implementasi Nilai-Nilai Belanegara Dalam Kehidupan Bermasyarakat, Berbangsa Dan Bernegara Bagi Tegaknya Keutuhan NKRI, Jurnal Islamica, Volu. 2 Nomor 1, 2014, Bandung: STAI Siliwangi.

Mahfud MD, Moh. 2012, Pancasila Memang Sakti, Jakarta: Sekretariat Jenderal MPR RI.

Notonegoro, 1980, Beberapa Hal Mengenai Filsafah Pancasila, Jakarta: Pantjoran Tujuh.

Republika, Bela Negera di Usia Dini, Jakarta, Republika, 2015.

Ryacudu, Ryamizard. 2015. Tanamkan Nilai Kebangsaan dan Cinta Tanah Air Sejak Dini, Kementerian Pertahanan dan Kemeterian Pemberdayaan Perempuan Dan Perlindungan Anak Republik Indonesia, http://www.kemenpppa.go.id/index.php /page/read/29/162/press-releasetanamkan-nilai-kebangsaan-dan-cintatanah-air-sejak-dini, diakes pada tanggal 5 Desember 2017.

Sekretariat Jenderal MPR RI, 2012, Presiden Bicara Pancasila, Jakarta: Sekretariat Jenderal MPR RI. 